\title{
CONCEPT AND STRUCTURAL COMPONENTS OF SOCIAL SKILLS
}

\author{
Margarita Jurevičienė $\dot{1}^{1}$ Irena Kaffemanienė ${ }^{1}$, Jonas Ruškus ${ }^{2}$ \\ Šiauliai universityl, Šiauliai, Lithuania \\ Vytautas Magnus University², Kaunas, Lithuania
}

\begin{abstract}
Research background. Though a variety of social skill explanations exist, in essence they give us plenty examples of controversial interpretation of social skill conception and classification. So, there is a problem of different semantic meanings in the concept of social skills and different classifications of them.

Research aims were to reveal the multidimensionality of the construct of social skills and to create a theoretical model of their structure.

Research method was theoretical analysis.

Discussion and conclusions. After studying various explanations of social skills, we observed that not only a great variety of their interpretations was revealed, but also there is a problem of different semantic meaning: some authors named the same behavioral categories as social competences, others - as social skills, yet others - as social abilities, etc. In addition, the authors present a variety of different classifications of social skill groups and the different structures of social skills. In this theoretical research we tried to analyze and systemize the explanations of social skills with reference to the data of scientific research from various countries.

As a result of analysis and systemization of scientific data we offer a model of social skill structure and give interpretation of social skill concept as a multidimensional construct created from integrative, overlapping and supplementing each other structural components of: 1) interaction skills; 2) communication skills; 3) participation skills; 4) emotional skills; and 5) social cognition skills. Each component of social skills is made up of certain behavioral abilities.
\end{abstract} skills.

Keywords: interaction skills; communication skills; participation skills; emotional skills; social cognition

\section{INTRODUCTION}

$\mathbf{R}$ elevance of the problem. In scientific literature there is a variety of social skill conceptions. Social skills are explained as an assumption of a wholesome social life (Osit, 2008), which are essential in pursuance of personal sovereignty, ability to adapt to social situations, to express themselves and understand others (Colombero, 2004); to communicate avoiding conflicts, to maintain good interpersonal skills (Brodeski, Hembrought, 2007); social skills are an important condition for a harmonious existence in a social group, a possibility for an individual to act effectively in a social environment, and an assumption of a successful socialization. Research results prove that a person, who has acquired social skills and learnt to solve problems, can undergo changes more easily, and adapt to the circumstances; due to insufficient social skills an individual becomes dependent on the surrounding people (Gedvilienè, Baužienè, 2008). Undoubtedly, social skills determine the quality of person's social functionality and the quality of social situations' management, as well as make a great influence on the quality of personal and social life. Education and possession of these skills enable individuals to effectively communicate, meet the needs, relate 
with others and be able to interact with people in various situations.

So, the effect of social environment on social skill development is analyzed in plenty of research, and an undoubtful importance of social skills for successful socialization is emphasized. However, studying various explanations of social skills, we can observe that scientists revealed a variety of interpretations. For example, some authors name the same behavioral categories as social competences, others - as social skills, yet others as social abilities, etc. Though variety of social skill concepts shows a great interest of scientists in this problem, in general those studies do not explain the concept of social skills. In addition, the investigators do not have the same view of their structural components. Different authors explain the structure of social skills, selecting different values and varying criteria. That brings confusion in interpreting the concept of social skills in general. So, the problem exists because of using social skill concept in different semantic meanings as well as their different classification and different views of their structural components. It is necessary to find a single concept of social skills and explain their structure. Based on theoretical analysis of $t$ scientific sources, the authors of this article aim at answering the following problem: How can we define the concept of social skills? What structural components constitute the concept of social skills? What is the relationship between the concept of social skills and social abilities? How do we classify social skills?

Research aim was to reveal the multidimensionality of social skill construct and to create a theoretical model of social skills structure.

\section{THE CONCEPT OF SOCIAL SKILLS}

A number of authors attribute similar meanings or even use as synonymic concepts of social abilities, social skills, social competence. However, when analyzing the concept of skills, authors usually show different stages in the formation of any act - from the lowest level, which is named as ability, to the highest or automated level of the actions, which is called as skill (Jovaiša, 1993; Lepaite, 2003 et al.). So, skill is considered the highest level of performance of the action. The masterful application of skills in different situations or the perfect way of performing actions based on the knowledge, abilities and skills means a competence (Jacikevičius, 1994). According to D. Lepaitè (2003), a connecting link between skills and competence is the ability to apply the skills. Each personal competence is closely linked to the appropriate social skills and social abilities. Social competence extends to a variety of social functioning domains: not only as skills of personal relationships, communication, cooperation, but also as skills of self-management or skills of solving problems. S. Vaughn, A. Hogan (1990) also identified social competence relates to personal characteristics; according to the authors, social competence manifests as social cognition skills, effective communication and positive relations with others.

Theoretical analysis of scientific sources shows that the term of ,social ability" is used 1) as one of the elements of any social activities (Lepaite, 2003); 2) as the lower level of skills in the stage of their development (Jovaiša, 1993; Lepaitè, 2003). Social skills and their elements - social abilities - become apparent in all human social activities, when they carry out certain tasks and operate under certain circumstances (Trotter, Ellison, 2001).

In addition, authors often described social skills as the level or degree of personality, whereby a person demonstrates personal social knowledge and ability to manage social interaction (Hogan, Shelton, 1998); social skills are linked to a person's ability to initiate interactions, as well as an adequate response to other's behavior (Gresham, 2002). S. Cavell (1990) argue that social skills (such as overt behavior skills, social cognitive skills; emotional regulation skills, etc.) enable behavior which meets social expectations (standards of behavior).

Many authors recognize that social skills appear as an appropriate behavior (the ability to choose behavior according to the situation and meet the expectations of behavior, to express positive and negative feelings without the loss of social support, etc.). Social skills are demonstrated in a large variety of interpersonal contact and include the appropriate abilities of verbal and nonverbal reactions and individual perceptions under what circumstances and what behaviors will get environmental approval.

It is clear that a significant part of a person's social competence is determined by the quality of social skills. Consequently, the quality of social skills is important in all areas of human activity and thus social skills can be considered as one of the main measures of social competence. 
The analysis of scientific literature shows a particularly high diversity of conceptions of social skills. But there are several most prevalent explanations of social skills among the diversity of conceptions. For example, some of the conceptions interpret social skills as individual personality traits (trait model); other authors describe the social skills as part of behavioral components (molecular model); yet other authors define social skills as intrapersonal (self-understanding, self-esteem, self-regulation) and interpersonal abilities.

Trait model treats social skills as essential personal characteristics, which manifest themselves in a personal behavior style (McNary, 2003). Authors, representing trait model, argue that social skills are stable and long-lasting personality features, such as empathy - feeling in somebody's emotional state (Nezlek et al., 2001), sociability (Lieberman, Rosenthal, 2001); or an individual difference, which expresses itself in communication (Riggio, 1986). R. Malinauskas (2004) studied such social skills that essentially mean personal traits: "four essential social skills can be named as emotional expressiveness, emotional sensitivity, social expressiveness and social sensitivity" (p. 2). According to the author, emotional expressiveness includes both the need for communication and an attitude towards communication; the emotional sensitivity means an ability to recognize emotions of others; the social expressiveness includes both verbal expressiveness (abilities to initiate conversations and speak with someone) and the ability to receive and to understand verbal signals; and the main component of social sensitivity is the ability to follow social rules and norms.

Molecular model appeared as a response to the trait model. Authors of this model define social skills not as a durable set of personal traits, but as a person's ability to choose adequate behavior according to different contexts of social situations (McFall, 1982). Molecular model analyzes behavior in a specific situation and treats social skills as specific behavior that changes depending on the environment and situational factors (Argyle, Kendon, 1967). Molecular model accentuates notable behavior manifestations in each social situation (Danielson, Phelps, 2003); a complex of behavior abilities (Libet, Lewinsohn, 1973); communication, representing one's own rights and aspirations without violating those of others (Phillips, 1978).

Majority of social skill conceptions have some attributes of both theoretical models (trait model or molecular model). According to J. Burgoon and N. Dunbar (2000) and others, social skills are best understood through an interaction between an individual and environment; social skills manifest themselves in certain activities, situations, and social interactions. Subsequently explanations of social skills include both the trait and molecular models and show that social skills are best understood when the personal traits and the situations, in which personality traits emerge, are being compared at the same time (Hochwarter et al., 2006).

In addition, social skills are defined from an intrapersonal (self-awareness, self-evaluation, self-control) and interpersonal perspectives (Raudeliūnaitè, 2007). According to A. Stravynski and D. Amdao (2001), social skills are described from an intrapersonal perspective as behavior that is typical of a personality in all situations and that refers to the person's self-perception. Selfperception and cognition of personal emotions, in D. Goleman's (2001) opinion, are the components of emotional intellect; it means an ability to understand, identify and manage one's own emotions and facilitate understanding situations in social life. Obviously, intrapersonal (or social cognition) skills are related to intellectual actions (self-analysis, reflection); and there is a close relation between intellectual strengths, academic achievements, and social skills (Welsh et al., 2001).

From the perspective of interpersonal model, social skills are explained as a behavior that corresponds to the way of some interaction; and thus social skills are specific behavior which can be learnt to apply in certain situations (Raudeliūnaite, 2007).

Relation between intrapersonal and interpersonal skills can be described in the following way: intrapersonal skills (understanding oneself and own emotions, values, and abilities) create assumptions to develop the interpersonal skills (recognizing and understanding the feelings and moods of others, orienting in social situation, etc.). Both intrapersonal and interpersonal skills help a person to create adequate interaction with oneself and with social environment.

When describing social skills, researchers choose different criteria. In some occasions, for the explanation of social skills an observable behavior is selected as a reference point, which meets social norms and potentially should receive a positive social response; social skills, in F. M. Gresham's (2002) opinion, condition adequate actions. Authors 
who hold this position describe social skills as a behavior that meets the norms, or as compliance of instruction, which helps the individual to communicate: to ask questions, ask for help, meet the needs, get along with others, maintain positive relations, protect one's own and other's self-esteem. Matson et al. (2008) and others define social skills as observable (for example, eyesight contact, gesticulation) and measurable (i. e., such that can be evaluated) behavior, by which an acceptance is sought in interpersonal exchange. Similar definitions of social skills are detected in the works of many authors. For example, J. Chadsey-Rusch (1992) defined social skills as a learnt, goal-oriented, societal norms guided behavior, which depends on a specific situation, social context; the author notes that societal behavior includes observable and unobservable, cognitive and emotional social proficiency elements, by which a positive or neutral response from other people is encourage, avoiding the negative one. Thus, social skills are analyzed from the social reasoning perspective (Cook et al., 2008). Authors emphasized an evaluative aspect of social skills, and highlighted positive effect of social behavior proficiency. This is shown by interpretations of social skills by many authors. Social skills are socially acceptable behavior which is described by an ability to understand social expectations and behave according to those expectations and situations; according to F. M. Gresham (2002), L. W. Stone et a.l (2002), social skills allow a person to communicate effectively, avoid unfavorable people's reactions, and receive important social results - acceptance, popularity, positive opinion about a person; social skills help to effectively communicate and avoid socially unacceptable response. With reference to these authors, a socially acceptable behavior meets societal expectations, social norms and, therefore, is favorably assessed.

In other cases, dynamism of social skills is accentuated; this manifests in adequacy of the chosen behavior to the situation; then, social skills are described as personality variables, which show person's flexibility, sensitivity to the needs of others (whether it would be based on empathy, or instrumental goals - Jarvin, Subotnik, 2006), ability to orient in shifting situations; social skills were described as specific situational behavior (different social skills are important in different situations), goal-oriented behavior (Norton, Hope, 2001). F. M. Gresham (2002) explains social skills as verbal and nonverbal behavior that does not depend on the situation (environmental circumstances, person's or other interaction members' needs and expectations).

Besides, from a qualitative point of view, social skills are also described as a level or extent according to which a person demonstrated social awareness and ability to manage the social interaction (Hogan, Shelton, 1998). There are also descriptions of social skills as moderators which help to regulate interpersonal relations and reach personal goals (Elijah, 2009).

It is important to note that the quality of social skills relates both with personal ability to initiate an interaction, and to an adequate feedback to the behavior of others (Gresham, 2002). Majority of authors acknowledge that social skills manifest as an adequate behavior (i. e. abilities to choose actions that correspond to the situation and expectations, abilities to express positive and negative emotions, without loosing social support). Such skills are demonstrated in a great variety of interpersonal contacts and include adequate verbal and nonverbal reactions and thus a person understands under which circumstances and what behavior is going to receive the approval of the surrounding people.

\section{STRUCTURAL COMPONENTS OF SOCIAL SKILLS}

Theoretical analysis proves that social skills of each area are composed of certain behavioral components - i. e. abilities that help the individual to recognize social signals and respond to them adequately, to behave in a way that a potential to receive support from the environment would be maximal (Walker et al., 2002).

Social skills can manifest themselves in abilities of different levels - starting with elementary communication (for example, eyesight contact), social perception abilities (such as understanding and interpreting social signals), specific behaviors, ways of interactions (for example, active listening, mutual communication, ignorance, etc.), which are applied by the individual when performing a social task; and finishing with communication skills i. e. effectively interact with others, adequately react, avoiding interpersonal conflicts, adapt to both simple, and complex situations (Matson et al., 2008). L. K. Elksnin and N. Elksnin (2000) and others are of a similar opinion: social skills manifest in learnt verbal and nonverbal (posture, eye contact, 
intonation, mimic) communication manners and abilities of sharing (Morrison et al., 2001), initiation of interactions (Heimann et al., 1995).

C. Canney and A. Byrne (2006) classify social skills according to the areas of their expression:

- foundation skills, manifesting in social interactions as basic abilities (eye contact, keeping an adequate personal space, gestures, mimic);

- interaction skills - they consist of the following abilities: to solve conflicts, wait for one's turn, initiate and close the conversation; interact with authorities;

- emotional skills are necessary for personal and other's awareness, they manifest as abilities to recognize and acknowledge the feelings of others, ability of empathy understanding body language and mimic, ability to determine whether another person can be trusted;

- cognitive skills are necessary in more complex situations of social interaction (social perception, self-observation, understanding of social norms, and the choice of an adequate behavior in different situations).

As the classification shows, certain abilities constitute social skills of each area. Similar units of social skill expression (abilities) of various areas can be found in the works of many other authors. U. Cornish and F. Ross (2004) classified social skills into recognition (perception) of consideration and social signals (signs), interaction (ability to understand the signals that others show and to change one's own behavior accordingly), action (ability to adapt), etc. Such social abilities as greeting, maintaining a conversation, making and maintaining a friendship, asking for help and instructing others help to perform daily interactions. S. N. Elliot et al. (2001) note that social skills reveal themselves as abilities to share, create relations, ask for help, etc.

- R. B. Rubin and M. M. Martin (1994) discern the following areas of social skills and abilities: communication skills: selfdisclosure ability; social relaxation ability (coping with negative reactions of others, one's own stress management);

- assertiveness ability - to protect one's own rights without denying the rights of others;

- expressiveness ability - to express thoughts, feelings in a verbal and nonverbal manner;

- emotional skills: empathy - awareness of other person's emotions; having interest in other person's words and feelings, taking care of another person; immediacy, openness shown in conversation - ability to speak (find a common topic, understand one another);

- supportiveness - understanding other without condemnation; orientation to help the other in solving his/her problems, and not the control of the other; empathy, and not estrangement, demonstration of equality, and not superiority;

- adjustability skills: environmental control ability which helps to reach one's own goals and meet one's own needs;

- interaction management abilities understanding a linguistic intercourse and mastering the communication etiquette, for example, turning to the interlocutor; rituals of initiation, development, and closing of the conversation, etc.

R. M. Rapee et al. (2000) discern social skills that come into play in nonverbal and verbal communication manners: body language - eye contact, posture, mimic; voice-quality - tone and altitude of voice, speech pace, clarity and interaction abilities: conversation - greeting, introducing oneself, initiation of conversations; expression of favor, benevolence, friendship - offering help, invitation, asking to join, expression of gentleness, complementing the other, sympathy, when others are hurt or sad; assertiveness - protection of one's rights, asking for help of information, expressing one's needs, refusal, coping with annoyance, harassment, etc. J. Zins et al. (2004) distinguish the following components in the structure of social skills: social comprehension skills (understanding and interpreting social factors), social behavior skills (creation of positive relations, responsible decision-making; constructive and ethical management of difficult situations), and emotion management skills (recognition and control of emotions; sympathy and care for others).

In the works of many authors, social skills are basically studied as interpersonal and intrapersonal, even though they are not always treated this way. R. Raudeliūnaitè (2007) perceives intrapersonal skills as self-awareness, self-evaluation, and selfcontrol skills; interpersonal - making a verbal and nonverbal contact, mutual interaction, conflict resolution skills. In the opinion of other authors, the following abilities are attributed to the intrapersonal skills: self-esteem, emotional self-awareness, assertiveness, independence, and self-realization; and interpersonal abilities empathy, social responsibility, and maintaining 
interpersonal relationships; adaptability, research of reality and compliancy to the rules, as well as problem solving; stress management - abilities of resistance to stress and control impulsiveness; positiveness, optimism (Bar-On, Parker, 2000).

Other authors discern essentially the same or similar components in the structure of social skills:

- self-cognition - ability to get to know and evaluate oneself, one's character, strengths and weaknesses (Gailienè et al., 1996) and/ or self-awareness, i. e. abilities to recognize emotions (emotional self-perception); fairly assess one's own strengths; have confidence in oneself (Goleman, 2001);

- self-control - abilities to control emotions, cope with stress, impulses; motivate oneself to overcome difficulties; determine and observe the progress of personal and academic goals; emotional control; trust in others; consciousness; adjustability; goal achievement; initiative (Goleman, 2001) and / or control of emotions (empathy, overcoming stress, etc.) - understanding of one's own and others' emotions and knowing, how they impact the behavior and health (Gailiene et al., 1996);

- social awareness - abilities to understand the environment by observing others; acknowledge individual and group differences and similarities; understanding the feelings of others; orientation in services; organizational consciousness (Goleman, 2001);

- effective communication - ability to initiate and maintain positive relations with the surrounding people; express oneself in verbal and nonverbal ways that are acceptable to the culture and situation (Gailienè et al., 1996), and relation management - abilities to initiate communication; resist an inadequate social pressure; constructively control conflicts (Goleman, 2001);

- decision-making - abilities to analyze information and experience, analyze alternative solutions and their outcomes; make the most rational and optimal decisions (Gailienè et al., 1996), and the ability to make decisions in conflict situations (Gevorgianienè, 1999).

A. Bellacket et al. (2004) distinguish the following components of social skills: expressive behavior - the content of speech and paralinguistic characteristics (speech pace, voice intensity, intonation); nonverbal behavior (eye contact, pose, mimic/face expression, distance from the interlocutor); social perception or receptive behaviors - attentiveness to signals, their interpretation, recognition of emotions; interactive behavior: reaction speed, social encouragement, turn-taking; situation factors - awareness of social traditions and

norms, following those norms, and their application in specific situations.

In the structure of social skills many authors discern verbal, nonverbal, and paralinguistic abilities; social perceptions; social information processing and decision-making; reaction that meets the norms, expectations of society and the situation; assertiveness; speech; control and expression of emotions (Kopelowicz et al., 2006), and other abilities.

As a result of scientific data systematization, the authors of this article grounded a structural model of social skills (see Figure).

We think it is reasonable to classify social skills by functioning areas: 1) interaction skills; 2) communication skills; 3) participation skills; 4) emotional skills; 5) social cognition skills. Social skills of each area are divided into smaller units - social abilities. The structural components of social skills and abilities are described below in more detail.

Interaction skills consist of management and control abilities of mutual interactions which include the management of one's own behavior, and the abilities to manage and control the interaction of other with him/her (for example, the ability to resist the negative effect and etc.). Thus, social interaction manifests in the effect that communicators make on one another.

Communication skills distinguish in a complex structure. Analyzing the structure of communication skills, it becomes clear that they consist of abilities of various complexity levels. In the works of various authors, communication skills are firstly related to the abilities to initiate and maintain verbal and nonverbal contact (Gevorgianienè, 1999; Rapee et al., 2000; Bellack et al., 2004; Cornish, Ross, 2004; Canney, Byrne, 2006; Raudeliūnaite, Paigozina, 2009).

On the other hand, nonverbal contact and communication abilities that are followed by a verbal communication are no less important, and, in some cases (for example, given there is a speech underdevelopment) nonverbal communication takes over and substitutes usual (verbal) communication. 
Figure. Structural model of social skill components

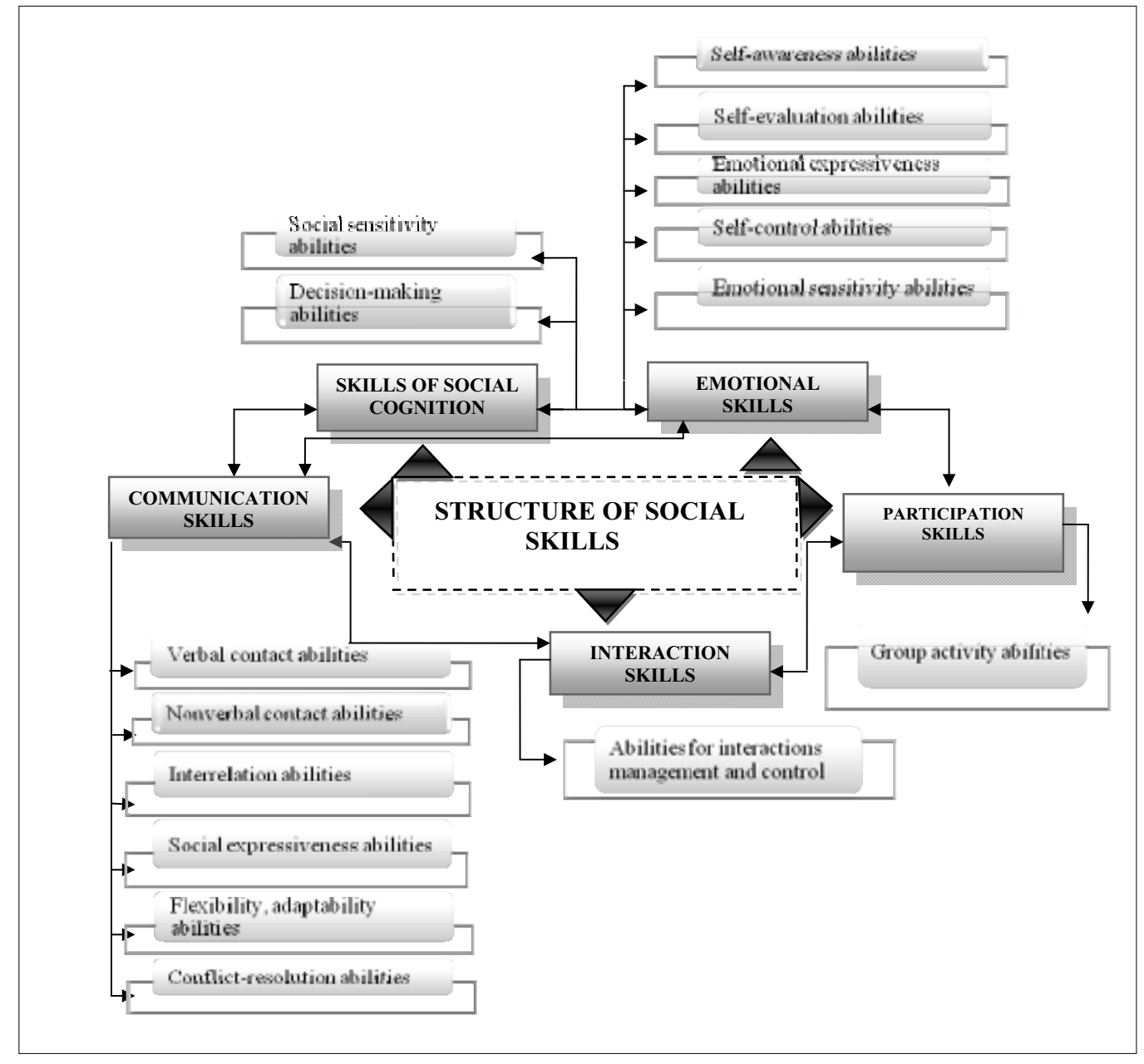

However, communication skills manifest not only in the easiness of contact initiation, but also in more complex abilities of maintaining interpersonal relations (Gailienè et al., 1996; Cornish, Ross, 2004). Social expressiveness is also needed when communicating (Rapee et al., 2000; Cornish, Ross, 2004; Malinauskas, 2004), as well as, flexibility and adjustability abilities (Rapee et al, 2000; Goleman, 2001;Cornish, Ross, 2004), and conflict resolution abilities (Gevorgianienè, 1999; Cornish, Ross, 2004 et al.).

Theoretical analysis proves that co-operation skills are often mentioned next to communication skills. However, authors describe the structure of co-operation skills basically as activity abilities, and not social ones. For instance, activity and co-operation skills are such as activity planning, activity organization and evaluation, participation in group activity (Raudeliūnaitè, Paigozina, 2009).

Emotional and social cognition skills are integrating and overlapping, i.e., they manifest in various human communication and participation activities. Components of emotional skills are abilities of self-awareness (Gailienè et al., 1996;
Bar-On, Parker, 2000; Goleman, 2001; Cornish, Ross, 2004) and self-evaluation (Raudeliūnaite, 2007); those abilities help individual to understand oneself in social interaction situations; and emotional expressiveness (Malinauskas, 2004) or self-revelation abilities - they help to positively reveal oneself to others. It is important to understand others in communication situations and emotional sensitivity abilities are necessary in order to do this (Malinauskas, 2004); self-regulation (BarOn, Parker, 2000), self-management or self-control abilities (Goleman, 2001; Raudeliūnaitè, 2007) help to behave adequately.

Emotional expressiveness and emotional sensitivity are the ones that integrate with communication abilities. According to R. Malinauskas (2004), emotional skills enrich and enliven verbal and nonverbal communication. The author states that emotional expressiveness belongs to the area of nonverbal information transfer and includes not only the ability to express the need for communication, but also shows the individual's ability to express emotions in a manner that is understandable and acceptable to the surrounding 
people. Emotional sensitivity means the recognition of other's emotions, and emotional control - ability to control and regulate one's emotional states and their nonverbal expression, as well as to mask one's emotional state, and avoid a spontaneous burst of emotions (Malinauskas, 2004).

Thus, emotional skills manifest in two ways on the one hand, they aid the person to understand oneself and to cope with his/her emotions, also to control oneself while communicating and participating in a common activity with others; on the other hand, emotional skills help to understand the partners of communication or a common activity.

Analyzing H. Bless et al. (2004), J. I. M. Carpendale and C. Lewis (2006) and other authors' works we identified social cognitive skill component in the structure of social skills. Cognition skills undoubtedly condition the quality of person's social functioning (firstly, communication and participation in activities). Their basis is social norms which regulate behavior and knowledge (cognitive level). The practical level of social cognition skills is social sensitivity which aids to decode social signals (abilities of perception of social signals), assess the situation (social situation evaluation abilities), by comparing it to the knowledge about social norms (cognition abilities of social norms), as well as it helps to make decisions about a behavior that would be adequate to the situation, and when needed, to solve problems (decision-making abilities). So, social sensitivity is as ability to understand (decode) verbal signals, understand and follow social norms which regulate adequate social behaviors (Malinauskas, 2004), and problem-resolution ability is related to cognitive abilities. Besides, according to D. P. Hallahan and J. N. Kauffman (2003), social cognition skills (to understand and memorize requirements for actions and behaviors) relate to emotional skills (selfregulation, and self-control abilities). The basis for social sensitivity is abilities of social norm awareness, recognition and evaluation of emotional state of partners, etc. Both the knowledge of social norms and practical orientation to social norms in various social situations require a high level of social and emotional intellect.

Social cognition skills reflect person's orientation in social life, understanding the logics of interpersonal relations, expectations from the surrounding people's viewpoint and behavior control corresponding to expectations.

According R. Malinauskas (2004), social skills of each area reveal themselves by the ability to send and interpret verbal and nonverbal (body language, mimic, emotional) information, and to control the quality of one's own communication. Similar standpoint is found in R. Raudeliūnaitè's (2009) research. When analyzing components of social skills, the author chose communication (interaction, perception) and intercourse skills as an essential reference point.

In summary, it can be stated that communication skills are essential in the structure of social skills; however, communication skills are closely related to emotional and social cognition skills; besides, communication skills manifest in observable behavioral forms - interaction management and control abilities. So, communication induces the development of all other social skills: helps to learn ways to express socially acceptable behavior and emotions, control the expression of behaviors and emotions, constructively resolve conflicts and strengthen interrelationships. On the other hand, communication is both the factor and the presumption of social skill formation; communication and other social skills are the result of social and educational interactions.

\section{CONCLUSION AND PERSPECTIVES}

Analysis of scientific sources has proved that social skills are being studied from various point of view: as consistent personality characteristics; as behavioral components; as a behavior, which corresponds to societal expectations and adequately shifts depending on the context (peculiarities of the environment and individual), etc. Some authors named the same behavioral categories as social competence, others - as social skills, yet others - as social abilities. Scientists note that social skills help to orient in social situations with more success; however, the quality of social skills and social abilities can be individual, and this may cause an unequal level of social adjustability and social functioning.

Also diversity of social skill classification was discovered in various scientific sources. Social skills were classified into categories according to the ways of their expression (verbal, nonverbal), areas of expression (intrapersonal, interpersonal). It is typical that many scientists classify social skills into categories or types of skills according to their level of complexity. Describing the conception of social skills, scientists reveal different levels of their complexity: from basic (eye contact, limited verbal response to limited social stimuli from the 
environment) to complex social skills (decisionmaking, leadership, etc.).

The variety of interpretations and classifications, possibly, can be explained by differing methodological regulations of research.

In our opinion, the concept and design of social skills is best explained in terms of system theory. System theory allows to analyze the complex structures, events and processes in different aspects and evaluate the relationships between system components (von Bertalanaffy, 2001; etc.). In addition, system theory emphasizes the complexity of human interaction with the environment and people's ability to not only to give up to the environmental impacts, but also the ability to change even a variety of environmental factors on them (von Bertalanaffy, 2001; Mulej, 2007).

Based on the analysis of scientific research, we revealed the multidimensionality of social skills' construct and a theoretical model of structure of social skills. We think that social skills can be interpreted as a complex multidimensional construct of integrated, overlapping and supplementing each other structural components of 1) interaction skills;2) communication skills; 3) participation skills; 4) emotional skills; and 5) social cognition skills. Each of those structural components of social skills relate to each other by close systematic ties and the skills of every area consist of various smaller units - social abilities, which are important not only for one area of skills. Social abilities of each social skill component integrate and overlap into the more than one area of person's social functioning. Communication is both the factor and the presumption of social skills formation. So communication skills are essential in the structure of social skills. Communication and other social skills are the result of social and educational interactions.

Various individual's social functioning areas of an individual are inter-related components of social skills, such as interaction, communication, participation, emotional, social cognition skills. Therefore, based on system theory perspective, advances in one area of social skills, have an effect on other areas of social skills.

In perspective we believe that social skill structural model based on systems theory approach can be useful both for the social skill assessment purposes, as well as for educational purposes. Social skills structural model can explain and clearly show which personal social skills and abilities need more attention of educators. In the area of solving educational problems, the main attention must be given to training specific social abilities that are parts of various social skills.

\section{REFERENCES}

Argyle, M., Kendon,A. (1967). The experimental analysis of social performance. Advances in Experimental Social Psychology, 3, 55-98.

Bar-On, R., Parker, J. D. A. (2000). Bar-On Emotional Quotient Inventory: Youth Version (Bar-On EQ-i:YV) Technical Manual. Toronto, ON: Multi-Health Systems Inc.

Bellack, A., Mueser, K., Gingerich, S., Agresta, J. (2004). Social Skills Training for Schizophrenia: A Stepby-Step Guide. New York: The Guilford Press.

von Bertalanffy, L. V. (2001). General System Theory: Foundations, Development, Applications. Revised Editon. New York: George Braziller Inc.

Bless, H., Fiedler, K., Strack, F. (2004). Social Cognition. Hove and New York: Psychology Press.

Brodeski, J., Hembrought, M. (2007). Improving Social Skills in Young Children. An Action Research Project. Chicago, Illinois: Saint Xavier University.

Burgoon, J., Dunbar, N. (2000). An interactionist perspective on dominance-submission: Interpersonal dominante as a dynamic, situationally contingent social skill. Communication. Monograph, 67, 96-121.

Canney, C., Byrne, A. (2006). Evaluating circle time as a support to social skills development - reflections on a journey in school based research. British Journal of Special Education, 33 (1), 19-24.

Carpendale, J. I. M., Lewis, C. (2006). How Children Develop Social Understanding. Oxford: Blackwell.

Cavell, S. (1990). Conditions Handsome and Unhandsome: The Constitution of Emersonian Perfectionism. Chicago: University of Chicago press.

Chadsey-Rusch, J. (1992). Toward defining and measuring social skills in employment settings. American Journal on Mental Retardation, 96 (4), 405.

Colombero, G. (2004). Nuo žodžiu i dialoga. Psichologiniai asmenu tarpusavio komunikacijos aspektai. Vilnius: Kataliku pasaulio leidiniai.

Cook, C. R., Gresham, F. M., Kern, L. et al. (2008). Social skills training for secondary students with emotional and/or behavioral disorders: A review and analysis of the meta-analytic literature. Journal of Emotional and Behavioral Disorders, 16, 131-144.

Cornish, U., Ross, F. (2004). Social Skills Training for Adolescents with General Moderate Learning Difficulties. London: Jessica Kingsley.

Danielson, C. K., Phelps, C. R. (2003). The assessment of children's social skills through self-report: A potential screening instrument for classroom use. Measurement 
and Evaluation in Counseling and Development, 35, 218-229.

Elijah, W. D. (2009). Sociopsychometric Measures: Social Skills and Social Competence. Portu: Fernando Press.

Elksnin, L. K., Elksnin, N. (2000). Teaching parents to teach their children to be prosocial. Intervention in School and Clinic, 36 (1), 27-35.

Elliott, S. N., Malecki, C. K., Demaray, M. K. (2001). New directions in social skills assessment and intervention for elementary and middle school students. Exceptionality, 9, 19-32.

Gailienè, D., Bulotaitè, L., Sturlienè, N. (1996). Aš myliu kiekvienq vaikq. Apie vaiku psichologinio atsparumo ugdyma. Vilnius: Valstybinis leidybos centras.

Gedvilienè, G., Baužienė, Z. (2008). Vaikų, turinčių judejjimo sutrikimu, socialinių gebejjimų ugdymas. Specialusis ugdymas, 1 (18), 158-168.

Gevorgianienė, V. (1999). Vidutiniškai sutrikusio intelekto ugdytiniu bendravimo gebejimu ugdymas: daktaro disertacija. Šiauliai: Šiauliu universitetas.

Goleman, D. (2001). An EI-based theory of performance. In C. Cherniss, D. Goleman, (Eds.), The Emotionally Intelligent Workplace (pp. 27-44). San Francisko: Jossey-Bass.

Gresham, F. M. (2002). Teaching social skills to highrisk children and youth: Preventive and remedial strategies. In M. R. Shinn, H. M. Walker, G. Stoner (Eds.). Interventions for Academic and Behavior Problems. II: Preventive and Remedial Approaches (pp. 403-432). Bethesda, MD: National Association of School Psychologists.

Hallahan, D. P., Kauffman, J. N. (2003). Ypatingieji mokiniai. Specialiojo ugdymo ivvadas. Vilnius.

Heimann, M., Nelson, K., Tjus, T., Gillberg, C. (1995). Increasing reading and communication skills in children with autism through an interactive multimedia computer program. Autism Development Disorders, 25, 459-480.

Hochwarter, W. A., Witt, L. A., Treadway, D. C., Ferris, G. R. (2006). The Interaction of Social Skills and Organizational Support on Job Performance. Journal of Applied Psychology, 91(2), 482-489.

Hogan, R., Shelton, D. (1998). A socioanalytic perspective on job performance. Human Performance, 11, 129-144.

Jacikevičius, A. (1994). Siela. Mokslas. Gyvensena. Vilnius: Žodynas.

Jarvin, L., Subotnik, R. F. (2006). Understanding elite talent in academic domains: A developmental trajectory from basic abilities to scholarly productivity. In F. A. Dixson, S. M. Moon (Eds.), The Handbook of Secondary Gifted Education (pp. 203-220). Waco, TX: Prufrock Press.

Jovaiša, L. (1993). Pedagogikos terminai. Kaunas: Šviesa. Kopelowicz, A., Liberman, R. P., Zarate, R. (2006). Recent advances in social skills training for schizophrenia. Schizophrenia Bulletin, 32, 12-23.

Lepaite, D. (2003). Kompetencija plètojančiu studiju programu lygio nustatymo metodologija. Kaunas: Technologija.
Libet, J. M., Lewinsohn, P. M. (1973). Concept of social skill with special reference to the behavior of depressed persons. Journal of Consulting and Clinical Psychology, 40, 304-312.

Lieberman, M., Rosenthal, R. (2001). Why introverts can't always tell who likes them: Multiasking and nonverbal decoding. Journal of Personality and Social Psychology, 80, 294-310.

Malinauskas, R. (2004). Socialinio rengimo itaka sporto pedagogu socialiniams igūdžiams. Acta paedagogica Vilnensia, 12, 1-8.

Matson, J. L., Cooper, C., Malone, C. J., Moskow, S. L. (2008). The relationship of self-injurious behavior and other maladaptive behaviors among individuals with severe and profound intellectual disability. Research in Developmental Disabilities, 29 (2), 141-148.

Matson, J., Mayville, E., Lott, J., Bielecki, J., Logan, R. (2003). A comparison of social and adaptive functioning in persons with psychosis, autism, and severe or profound mental retardation. Journal of Developmental and Physical Disabilities, 15, 57-65.

McFall, R. M. (1982). A review and reformulation of the concept of social skills. Behavioral Assessment, 4, 1-33.

McNary, S. W. (2003). Behavioral generalization and cognition in social skills training for people with schizophrenia [2012 08 14]. Internet link: http://www. charm.net/ smcnary/sstpaper.pdf

Morrison, L., Kamps, D., Garcia, J., Parker, D. (2001). Peer mediation and monitoring strategies to improve initiations and social skills for students with autism. Positive Behavior Interventions, 3 (4), 237-250.

Mulej, M. (2007). Systems theory: A worldview and/ or a methodology aimed at requisite holism/realism of humans' thinking, decisions and action. Systems Research and Behavioral Science, 24 (3), 347-357.

Nezlek, J., Feist, G., Wilson, F., Plesko, R. (2001). Day-to-day variability in empathy as a function of daily events and mood. Journal of Research in Personality, 35, 401-423.

Norton, P. J., Hope, D. A. (2001). Analogue observational methods in the assessment of social functioning in adults. Psychological Assessment, 13, 59-72.

Osit, M. (2008). Generation Text: Raising Well-Adjusted Kids in an Age of Instant Everything. New York: AMACOM.

Phillips, L. (1978). The Social Skills Basic Psychopathology: Alternative to Abnormal Psychology and Psychiatry. New York: Grunte \& Stratton.

Rapee, R. M., Wignall, A., Hudson, J. L., Schniering, C. A. (2000). Treating Anxiety in Children and Adolescents: An Evidence-Based Approach. California: New Harbinger.

Raudeliūnaitè, R., Paigozina, R. (2009). Vaikų, gyvenančių globos namuose, socialinių igūdžių raiškos ypatumai. Socialinis darbas, 8 (1), 138-146.

Raudeliūnaitè, R. (2007). Sutrikusio regèjimo paaugliu socialiniai igūdžiai ir ju ugdymo pedagoginès prielaidos: monografija. Šiauliai: Šiaulių universiteto leidykla. 
Riggio, R. E. (1986). Assessment of basic social skills. Journal of Personality and Social Psychology, 51, 649660.

Rubin, R. B., Martin, M. M. (1994). Development of a measure of interpersonal communication competence. Communication Research Reports, 11, 33-44.

Stone, W. L., Ruble, L., Coonrod, E., Hepburn, S., Pennington, M. (2002). TRIAD Social Skills Assessment Manual. Nashville, TN: Treatment and Research Institute for Autism Spectrum disorders.

Stravynski, A., Amdao, D. (2001). Social phobia as a deficit in social skills. In S. G. Hofmann, P. M. DiBartolo (Eds.), From Social Anxiety to Social Phobia: Multiple Perspectives (pp. 107-129). Needham Heights, MA: Allyn \& Bacon.

Troter, A., Ellison, L. (2001). Understanding competence and competency. In B. Davies, L. Ellison (Eds.), School Leadership for the 21st Century (pp. 36-53). London: RoutledgeFalmer.

Vaughn, S., Hogan, A. (1990). Social competence and learning disabilities: A Prospective Study.
In H. L. Swanson, B. K. Keogh (Eds.), Learning disabilities: Theoretical and Research Issues (pp. 175191). Hillsdale, NJ: Erlbaum.

Walker, S., Irving, K., Berthelsen, D. (2002). Gender Influences on Preschool Children's Social Problem Solving Strategies. Journal of Genetic Psychology, 163(2), 197-210.

Welsh, M., Park, R. D., Widaman, K., O’Neil, R. (2001). Linkages between children's social and academic competence: A longitudinal analysis. Journal of School Psychology, 39, 463-481.

Witt, L. A., Ferris, G. R. (2003). Social skill as moderator of the conscientiousness - performance relationship: Convergent results across four studies. Journal of Applied Psychology, 88, 809-821.

Zins, J., Weissbert, R., Wang, M., Walberg, H. (2004). Building Academic Success on Social and Emotional Learning: What does the Research Say? New York: Teachers College Press.

\title{
SOCIALINIŲ İŪ̄DŽIỤ SAMPRATOS IR STRUKTŪROS KOMPONENTŲ TEORINE் ANALIZE்
}

\author{
Margarita Jurevičienė ${ }^{1}$, Irena Kaffemanienè ${ }^{1}$, Jonas Ruškus ${ }^{2}$ \\ Šiauliu universitetas ${ }^{l}$, Šiauliai, Lietuva \\ Vytauto Didžiojo universitetas², Kaunas, Lietuva
}

\section{SANTRAUKA}

Tyrimo pagrindas. Socialiniu igūdžiu tyrimu gausa rodo didžiuli visų šaliu mokslininkų susidomèjimą šia problema, tačiau tokie tyrimai pasižymi nevienareikšme bei kontroversiška šiu igūdžių interpretacija ir iš esmès nepaaiškina jų struktūrinių ypatumų.

Tikslas - remiantis mokslinių šaltinių teorinès analizès duomenimis suformuluoti socialinių igūdžių sampratą atskleidžiant socialinių igūdžių konstrukto multidimensiškumą ir pateikti teorini socialinių igūdžių struktūros modelị.

Tyrimo metodas - teorinè analizè.

Aptarimas ir išvados. Atlikus mokslinių darbų teorinę analizę, atskleista ne tik socialiniu igūdžių aiškinimo ivvairovès problema, bet ir nevienoda klasifikacija bei susijusių sąvokų interpretacijos nevienareikšmiškumas. Kai kurie autoriai tas pačias elgesio kategorijas ivvardija skirtingai: vieni - kaip socialinę kompetencija, kiti - kaip socialinius igūdžius, dar kiti - kaip socialinius gebejjimus. Be to, aptinkamas ir prieštaringas socialiniu igūdžiu klasifikavimo į grupes bei kiekvienos srities socialiniu igūdžių sandaros (sudedamujų elementų) aiškinimas. Šio tyrimo metu susisteminus įvairių autorių pateiktas socialinių igūdžių koncepcijas, pasiūlyta interpretuoti socialinius igūdžius kaip asmens socialinès kompetencijos sudedamają dali. Straipsnio autorių nuomone, socialiniai tgūdžiai sudètingas multidimensinis konstruktas, sudarytas iš tarpusavyje integruojančių (persidengiančių) ir vienas kitą papildančių struktūrinių komponentų-igūdžių: 1) interakcijos; 2) bendravimo; 3) dalyvavimo; 4) emocinių; 5) socialinès kognicijos. Kiekvieną iš šių socialinių igūdžių struktūrinių komponentų sudaro atitinkamų socialinių gebejimu kompleksai, kuriuos sieja glaudūs sisteminiai ryšiai. Socialiniai gebejjimai yra socialiniu igūdžiu struktūriniai elementai.

Raktažodžiai: interakcijos, bendravimo, dalyvavimo, emociniai ir socialinès kognicijos igūdžiai. 